\title{
Effect of Ashwagandha (Withania somnifera) and Vitamin C on Hematological Profile and Carcass Traits of Broiler Birds
}

\author{
Probhakar Biswas $^{1}$, Ram Kumar Sharma ${ }^{2,}$ Avishek Biswas ${ }^{3 *}$ and Indrajit Kar ${ }^{1}$ \\ ${ }^{1}$ West Bengal University of Animal and Fishery Sciences, Department of Avian Sciences, \\ Mohanpur campus- 741252, \\ ${ }^{2}$ Lala Lajpat Rai University of Veterinary and Animal Sciences, Ex-Professor, Department of \\ Livestock Production Management, Hisar, Haryana, India \\ ${ }^{3}$ ICAR-Central Avian Research Institute, Izatnagar, Bareilly-243122 (U.P.), India \\ *Corresponding author
}

\begin{tabular}{l}
\hline Ke y w o r d s \\
Ashwagandha, \\
Vitamin C, \\
Hematological \\
value, Carcass \\
traits, Broiler \\
\hline Article Info \\
\hline $\begin{array}{l}\text { Accepted: } \\
\text { 07 September } 2020 \\
\text { Available Online: } \\
\text { 10 October } 2020\end{array}$ \\
\hline
\end{tabular}

\section{A B S T R A C T}

A study was conducted to estimate the effect of supplementing diets with vitamin $\mathrm{C}$ and Ashwagandha (Withania somnifera) on hematological parameters and carcass traits of broiler at hot weather. Two hundred and forty (240), day-old vaccinated commercial broiler chicks were procured from a private hatchery located at Hisar, Haryana, India. The chicks were distributed into 4 treatments having 4 replicates of 15 chicks in each replicate. $\mathrm{T}_{2}, \mathrm{~T}_{3}$ and $\mathrm{T}_{4}$ were formulated to contain an additional $1 \%$ Ashwagandha powder, $0.05 \%$ Vitamin $\mathrm{C}$ and combination of $0.5 \%$ Ashwagandha powder $+0.025 \%$ Vitamin $\mathrm{C}$ respectively whereas, $\mathrm{T}_{1}$ was served as control. Supplementations Ashwagandha with combination of vitamin $\mathrm{C}$ lead to significantly $(\mathrm{P}<0.05)$ higher concentration of hemoglobin over the control group. Control group $\left(\mathrm{T}_{1}\right)$ had significantly lower $(\mathrm{P}<0.05)$ TLC in comparison to the supplemented groups at high THI of above 80 which is considered as uncomfortable. There were significantly higher TLC in Ashwagandha $\left(\mathrm{T}_{2}\right)$ and combination $\left(\mathrm{T}_{4}\right)$ group in respect to Vitamin $\mathrm{C}\left(\mathrm{T}_{3}\right)$ and control groups $\left(\mathrm{T}_{1}\right)$. The control group had significantly $(\mathrm{P}<0.05)$ higher heterophil percent than all other groups. Ashwagandha, Vitamin $\mathrm{C}$ and their combination significantly $(\mathrm{P}<0.05)$ improved the carcass yield in hot weather. The giblet percentage of Vitamin $C\left(\mathrm{~T}_{2}\right)$ group was higher than Ashwagandha and control but similar to the combination $\left(\mathrm{T}_{4}\right)$ group. The result reveals that dietary supplementation of vitamin $\mathrm{C}$, Ashwagandha and their combination in broiler diet is beneficial for hematological values and carcass traits of broiler birds at hot weather.

\section{Introduction}

Stress in poultry production refers to detrimental effects of a variety of situations on the health and overall performance of birds. Poor environment is one of the impediments in exploiting full genetic potential of the birds. The stressful 
environment during excessive summer heat has detrimental effect on growth, feed efficiency, meat yield along with high mortality in poultry birds (Cahaner and Leenstra, 1992). High temperature (above $30^{\circ} \mathrm{C}$ ) along with high humidity in tropical counties like India further aggravates the situation. The comfort zone of poultry declines from $32^{\circ} \mathrm{C}$ at hatching to about $24^{\circ} \mathrm{C}$ at four weeks of age. Birds are susceptible to high temperature due to high normal body temperature $\left(40.1^{0} \mathrm{C}\right.$ to $\left.41.6^{\circ} \mathrm{C}\right)$, feathered body, fatty nature and absence of sweat glands. Detrimental effect of hot weather on the production can be minimized through proper feeding and managemental practices. In India, environmentally controlled houses are not practically feasible for economic reasons. Most of the farmers rear broiler birds in open sided houses, resulting in exposure of birds to hot weather and thus heat stress.

Medicinal plants have been used since ages in India for different purposes and medicinal plants like Ashwagandha (Withania somnifera), Amla (Phyllanthus embolica), Tulsi (Ocimum sanctum) and shilajit possess established anti-stress, adaptogenic and performance enhancing properties (Pradhan, 1995). Vitamin C is another commonly used anti-stress agent against summer heat and has shown positive effect on the performance of broiler birds as reported by McKee et al., (1997). Ashwagandha has conventionally been used in humans, so its proven anti-stress and growth promoting activity has not been exploited in commercial broiler farming. Using Withania somnifera in hot weather for its anti-stress and growth promoting activity can avoid abuses and occurrence of hormone, antibiotics etc. residues in meat and at the same time increase customer acceptance due to its being an herb.

The effects of a nutritional supply of Vitamin $\mathrm{C}$ in limiting the metabolic signs of stress and alleviation of the physiological consequences of stress are manifested in the performance, immunological competence and behavior of birds. Optimum responses in growth under heat stress seem to occur with supplements of about $250 \mathrm{mg}$ Vitamin $\mathrm{C} / \mathrm{kg}$ feed in laying hens (Whitehead and Keller, 2003). Lohakare et al., (2004) studied the effect of feeding methods (water vs. feed) of vitamin $\mathrm{C}$ on growth performance and characteristics of broiler chickens. They provided Vitamin C @ $10 \mathrm{ppm}, 20 \mathrm{ppm}$ and $5 \mathrm{ppm}, 10 \mathrm{ppm}$ through feed and water, respectively. Body yield was higher in the group provided Vitamin $\mathrm{C}$ in feed than water. Better performance in terms of body weight gain and performance index in broiler birds was reported by Biswas et al., (2012) in Ashwagandha and ascorbic acid supplemented groups.

Studies on vitamin $\mathrm{C}$ with combination of Ashwagandha (Withania somnifera) on hematological parameters and carcass traits of broiler are very limited. Therefore, the present study was designed and undertaken to examine the effects of vitamin $\mathrm{C}$ with combination of Ashwagandha on hematological parameters and carcass traits of broiler at hot weather.

\section{Materials and Methods}

\section{Housing and rearing of birds}

Two hundred and forty (240), day-old vaccinated commercial broiler chicks were procured from a private hatchery located at Hisar, Haryana, India. The chicks were distributed into 4 treatments having 4 replicates of 15 chicks in each replicate. The experiment had a randomized design (Snedecor and Cochran, 1985). The day-old chicks were reared under uniform husbandry conditions and provided with standard broiler ration. The same technicians provided feed, water, and collected data from the birds 
during the course of the experiment. The experiment followed the guidelines of 'Institutional Animal Ethics Committee'.

\section{Formulation of experimental diets}

The basal diet $\left(\mathrm{T}_{1}\right)$ contained $23.04 \%$ (0-4 wks) and $20.10 \%$ (4-6 wks) of crude protein (CP), $2800 \mathrm{kcal} / \mathrm{kg}$ (0-4 wks) and 2906 $\mathrm{kcal} / \mathrm{kg}$ (4-6 wks) of ME (Table 1). $\mathrm{T}_{2}, \mathrm{~T}_{3}$ and $\mathrm{T}_{4}$ were formulated to contain an additional $1 \%$ Ashwagandha powder, $0.05 \%$ vitamin $\mathrm{C}$ and combination of $0.5 \%$ Ashwagandha powder $+0.025 \%$ vitamin $\mathrm{C}$ respectively.

\section{Determination of hematological parameters}

Hematological study was performed by collecting blood from 12 birds from each experimental group (i.e. 3 birds from each replicate) which were selected randomly. Approximately $04 \mathrm{ml}$ of blood was derived from the jugular vein following all scientific measures at 6 weeks of age during the process of slaughter and sterile test tubes with anticoagulant (4\% sodium citrate) at a ratio of 1:10 were used. About $4 \mathrm{ml}$ of blood was collected without anticoagulant in the sterile glass test tubes for preparation of serum samples and the tubes containing blood were placed in a slanting position at room temperature for optimum clotting. After initial clotting the tubes were then placed in the refrigerator at $4{ }^{\circ} \mathrm{C}$ over night. Serum was then collected and was centrifuged at 1,000 rpm for 15 minutes to get rid of unwanted substances. The serum was then stored in the screw capped serum vial and preserved at $20^{\circ} \mathrm{C}$ until use. The hematological studies were performed within two hours of blood collection as per technique described by Shastry, (1983). Haemoglobin (Hb), Total Erythrocyte Count (TEC), Total Leukocyte Count (TLC), Differential Leukocyte Count (DLC) and Heterophil: Lymphocyte ratio (H: $\mathrm{L}$ ratio) were estimated.

\section{Determination of carcass traits}

At the end of the experiment (42 days), three birds from each replicate of the treatment (12 birds per dietary treatment, $n=48$ ) were selected randomly and sacrificed to determine the relative weight of the carcass (\% of live weight). The carcass was carefully dissected to ensure complete removal and $\%$ of live weight [dressed, eviscerated, giblet and drawn] measured to the nearest $1.0 \mathrm{~g}$.

\section{Statistical analysis}

The data were analysed using a statistical software package developed at the computer centre of the Institute, following the standard procedure for ANOVA (Snedecor and Cochran, 1985) and Duncan's multiple range test (Duncan, 1955) by comparing means for significant differences.

\section{Results and Discussion}

\section{Hematological parameters}

Effect of different treatments on hemoglobin concentration, total erythrocyte count (TEC), total leukocyte count (TLC), differential leukocyte count (DLC) comprising of heterophil and lymphocyte percentage and $\mathrm{H}$ : $\mathrm{L}$ ratio in hot weather has been given in the Table 3. Supplementation of Ashwagandha with combination of vitamin $\mathrm{C}$ lead to significantly $(\mathrm{P}<0.05)$ higher concentration of hemoglobin over the control group. Control group $\left(\mathrm{T}_{1}\right)$ had significantly lower $(\mathrm{P}<0.05)$ TLC in comparison to the supplemented groups. There were significantly higher TLC in Ashwagandha $\left(\mathrm{T}_{2}\right)$ and combination $\left(\mathrm{T}_{4}\right)$ group in respect to vitamin $\mathrm{C}\left(\mathrm{T}_{3}\right)$ and control groups $\left(\mathrm{T}_{1}\right)$. The control group had significantly $(\mathrm{P}<0.05)$ higher heterophil percent than all other groups. Vitamin $\mathrm{C}$ group had least heterophil percent where as $\mathrm{T}_{4}$ group birds were having similar heterophil percent with $T_{2}$ and $T_{3}$. Lymphocyte percent 
was significantly lower $(\mathrm{P}<0.05)$ in the control group $\left(\mathrm{T}_{1}\right)$ in respect to all other supplemented groups. $T_{3}$ group had lowest lymphocyte percent whereas $\mathrm{T}_{4}$ recorded similar lymphocyte percent with $\mathrm{T}_{2}$ and $\mathrm{T}_{3}$ groups. Heterophil: Lymphocyte ratio $(\mathrm{H}: \mathrm{L})$ was found to be significantly $(\mathrm{P}<0.05)$ higher in the control group. Least $\mathrm{H}$ : $\mathrm{L}$ ratio was in the Vitamin $\mathrm{C}$ supplemented diet group but it was similar to combination $\left(\mathrm{T}_{4}\right)$ group. $\mathrm{T}_{4}$ group had similar $\mathrm{H}$ : $\mathrm{L}$ ratio with $\mathrm{T}_{2}$ and $\mathrm{T}_{4}$ groups.

In the present study the hematological parameters showed significant alteration due to dietary supplementation with vitamin $\mathrm{C}$ and Ashwagandha during high environmental temperature and THI above 80 which is considered as uncomfortable. Available literature suggests that Ashwagandha has the potential to change haematological parameters. Jayram et al., (1993) also reported similar results in human. Akotkar, (2004) reported higher hemoglobin concentration in broiler supplemented with Ashwagandha. Significant increase in TLC and lymphocytes in mice (Agarwal et al., 1999) which is similar to the findings of the present study. Daisy et al., (2008) also reported higher $\mathrm{Hb}$, TEC and TLC in Ashwagandha supplemented broilers however Choudhari et al., (2006) reported no significant increase in haemoglobin concentration, RBC and WBC count in Japanese quail. Improved H: L ratio close to the normal level in the stressed broilers supplemented with Ashwagandha in combination with other herbs (Rajeshwar et al., 2001). Heat stress affected the blood parameters in broilers. Altan et al., (2003) reported raised $\mathrm{H} / \mathrm{L}$ ratio in heat stressed birds, which is in accordance with the findings of the present study. Decreased $\mathrm{Hb}$ concentration and TEC in female birds (Bedanova et al., 2003) and decrease in the lymphocyte percent (Puvadolpirod et al., 2000), increase of heterophil percent and the rise in ratio of $\mathrm{H}$ : $\mathrm{L}$ in heat stress conditions in broilers are in agreement with the present findings obtained (Puthpongsiriporn et al., 2001) in the control group birds.

Lower level of $\mathrm{Hb}$ in the control group birds is probably due to the effect of high environmental temperature which may lead to changes in the distribution of iron in birds (Jamadar and Jalnapurkar, 1995). Ashwagandha alone or in combination with vitamin $\mathrm{C}$ improved $\mathrm{Hb}$ in respect to the control, which may be due to its anti-stress and haematinic activity. Ashwagandha is also highly rich in iron content (Gupta and Rana, 2007) which might be a reason for the better availability of iron for hemoglobin synthesis. Vitamin $\mathrm{C}$ group also registered better $\mathrm{Hb}$ may be due to its anti-stress activity. During heat stress due to panting there could be possibilities of oxidative stress, respiratory alkalosis and thus an overproduction of free radicals in the body. Maintenance of normal cell functions in the presence of oxygen largely depends on the efficiency of tissue protection against free radicals mediated oxidative stress. Bhattacharya et al., (1997) reported that glycol with anolides, the active principles of Ashwagandha to increase concentrations of the antioxidant enzymes viz. superoxide dismutase (SOD), catalase (CAT) and glutathione peroxidases (GPx). This could be beneficial for healthy erythrocytes in birds since cell membranes contain a high percentage of polyunsaturated fatty acids which are readily attacked by free radical, bringing about the disintegration of membrane, but an increased antioxidant activity in erythrocytes ensures proper and rapid elimination of reactive oxygen species (ROS) that could be formed during heat stress and thereby protecting the integrity of erythrocyte membrane. Glutathione found in almost all living cells is considered the master antioxidant of the body. Body utilizes glutathione chiefly to detoxify many toxins, 
maintain cellular redox potential, erythrocytes membrane integrity, etc. (Kidd, 1997). Oral supplementations of vitamin $\mathrm{C}$ have a significant effect on raising the glutathione levels in the liver and other tissues. Oxidative stressors can deplete Glutathione in extreme environmental conditions which might have been compensated in the supplemented groups.

Decrease in the TLC in heat stress may be as a result of involution of lymphoid organs. Increase in the percentage of heterophil is the most approved haemopoietic sign of stress. Decrease in the circulating lymphocytes may be as a result of cell destruction or the redistribution of cells to those out of the circulation. It may also be due to decreases in vessel permeability which limits leukocytes infiltration and the increase in the passing of the heterophil from the bone marrow to blood circulation. It is also assumed that Ashwagandha, vitamin $\mathrm{C}$ and their combination provides adaptation to stress by protecting the immune system from the negative effects of corticosteroids. Vitamin C, Ashwagandha and combination may inhibit ACTH and decrease the release of glucocorticoids and mineralocorticoids in the adrenal gland, and nor-epinephrine from sympathetic nerve ends.

Table.1 Composition of basal experimental diets ( $\mathrm{kg} / 100 \mathrm{~kg}$ feed)

\begin{tabular}{|c|c|c|}
\hline \multirow[t]{2}{*}{ Ingredients } & \multicolumn{2}{|c|}{ Period } \\
\hline & $0-4$ wks & 4-6 wks \\
\hline Maize $(k g)$ & 40.0 & 52.0 \\
\hline Soybean meal $(\mathrm{kg})$ & 20.0 & 14.0 \\
\hline Rice polish $(\mathrm{kg})$ & 12.0 & 10.0 \\
\hline $\begin{array}{l}\text { Deoiled rice polish } \\
(\mathrm{kg})\end{array}$ & 8.70 & 5.70 \\
\hline Groundnut cake ( $\mathrm{kg}$ ) & 11.0 & 10.0 \\
\hline Fish meal (kg) & 6.00 & 6.00 \\
\hline Mineral mixture $(\boldsymbol{k g})$ & 2.30 & 2.30 \\
\hline Crude Protein (\%) & 23.04 & 20.10 \\
\hline $\begin{array}{l}\text { ME }(\mathbf{k c a l} / \mathbf{k g}) \\
\text { (calculated) }\end{array}$ & 2800 & 2906 \\
\hline \multicolumn{3}{|c|}{ Feed additives (g/100 $\mathrm{kg}$ of ration) } \\
\hline Spectromix (g) & 10 & 10 \\
\hline Spectro BE $(g)$ & 20 & 20 \\
\hline Cocciwin $(g)$ & 50 & 50 \\
\hline Choline chloride ( $g$ ) & 50 & 50 \\
\hline Lysine $(g)$ & 50 & 50 \\
\hline DL- methionine (g) & 150 & 150 \\
\hline
\end{tabular}

Mineral mixture (salt free): Each g of mineral mixture contained: $200 \mathrm{mg}$ of $\mathrm{FeSO}_{4} \cdot 7 \mathrm{H}_{2} \mathrm{O}, 20 \mathrm{mg}$ of $\mathrm{CuSO}_{4} \cdot 5 \mathrm{H}_{2} \mathrm{O}$, $200 \mathrm{mg}$ of $\mathrm{MnSO}_{4} \cdot \mathrm{H}_{2} \mathrm{O}, 150 \mathrm{mg}$ of $\mathrm{ZnSO}_{4} \cdot 7 \mathrm{H}_{2} \mathrm{O}, 1 \mathrm{mg}$ of $\mathrm{KI}$.

Spectromix: Powder (Ranbaxy Animal Health, New Delhi-65). Each gm contained vitamin A (retinol)-82,500 IU, vitamin D3 (cholecalciferol)-12,000 IU, vitamin $\mathrm{B}_{2}$ (riboflavin)- $50 \mathrm{mg}$ and vitamin $\mathrm{K}$ (menadione)-10 $\mathrm{mg}$.

Spectro BE: Powder (Ranbaxy Animal Health, New Delhi-65). Each gm contained vitamin $\mathrm{B}_{1}$ (thiamin)- $8 \mathrm{mg}$, vitamin $\mathrm{B}_{6}$ (pyridoxine)- $16 \mathrm{mg}$, vitamin $\mathrm{B}_{12}$ (cobalamin)- $80 \mu \mathrm{g}$, niacin- $120 \mathrm{mg}$, calcium pentothenate $-80 \mathrm{mg}$, vitamin E (tocopherol)- $160 \mathrm{mg}$, L-lysine hydrochloride- $10 \mathrm{mg}$, DL-methionine- $10 \mathrm{mg}$ and calcium - $260 \mathrm{mg}$. Cocciwin: Dinitro-O-Toluamide, Lysine: Contained 98\% lysine, DL- methionine: Contained $98 \%$ methionine. 
Table.2 Average macro and micro environmental temperature, relative humidity and temperature humidity index during the different growth periods

\begin{tabular}{|c|c|c|c|c|c|c|c|c|c|c|c|}
\hline \multirow[t]{3}{*}{ Week } & \multicolumn{4}{|c|}{ Macro Environment. } & \multicolumn{4}{|c|}{ Micro Environment. } & \multicolumn{3}{|c|}{$\begin{array}{c}\text { Temperature } \\
\text { Humidity Index (THI) }\end{array}$} \\
\hline & \multicolumn{2}{|c|}{$\begin{array}{c}\text { Average } \\
\text { Temperature }\left({ }^{\circ} \mathrm{C}\right)\end{array}$} & \multicolumn{2}{|c|}{$\begin{array}{l}\text { Average } \\
\text { R.H (\%) }\end{array}$} & \multicolumn{2}{|c|}{$\begin{array}{c}\text { Average } \\
\text { Temperature }\left({ }^{\circ} \mathrm{C}\right)\end{array}$} & \multicolumn{2}{|c|}{$\begin{array}{l}\text { Average } \\
\text { R.H (\%) }\end{array}$} & \multirow{2}{*}{$\begin{array}{c}\text { Average } \\
\text { Temperature } \\
\left({ }^{\circ} \mathrm{F}\right)\end{array}$} & \multirow{2}{*}{$\begin{array}{c}\text { Average } \\
\text { R.H. } \\
(\%)\end{array}$} & \multirow[t]{2}{*}{ THI } \\
\hline & Max & Min & Max & Min & Max & Min & Max & Min & & & \\
\hline $0-2$ & 37.8 & 26.7 & 76 & 49 & 36.4 & 28.7 & 77 & 52 & 90.5 & 64 & 84.0 \\
\hline $2-4$ & 35.4 & 26.3 & 88 & 64 & 34 & 29.4 & 90 & 67 & 89.0 & 79 & 85.4 \\
\hline 4-6 & 35.5 & 25.9 & 84 & 55 & 35.4 & 27.3 & 86 & 58 & 88.4 & 72 & 83.7 \\
\hline
\end{tabular}

$\mathrm{THI}=\mathrm{T}-0.55 *(1-0.01 \mathrm{RH}) *(\mathrm{~T}-58)$. (The values have been calculated using micro environment observations.). Where ' $\mathrm{T}$ ' is the air temperature in ${ }^{\circ} \mathrm{F}$ and $\mathrm{RH}$ is relative humidity in percent

Table.3 Effect of vitamin C, Ashwagandha (Withania somnifera) and their combination on hematological parameters of broiler birds during hot weather (Mean \pm S.E.M; $N=60$ )

\begin{tabular}{|c|c|c|c|c|c|c|}
\hline Treatments & $\begin{array}{c}\text { Hemoglobi } \\
\text { n }(g / d l)\end{array}$ & $\begin{array}{c}\text { TEC } \\
\left(10^{6} / \mathrm{mm}^{3}\right)\end{array}$ & $\begin{array}{c}\text { TLC } \\
\left(10^{3} / \mathrm{mm}^{3}\right)\end{array}$ & $\begin{array}{c}\text { Heterophil } \\
(\%)\end{array}$ & $\begin{array}{c}\text { Lymphocyte } \\
(\%)\end{array}$ & H:L ratio \\
\hline$T_{1}$ (Control) & $8.36^{\mathrm{b}}$ & $3.25^{\mathrm{b}}$ & $31.33^{\mathrm{c}}$ & $34.60^{\mathrm{a}}$ & $58.85^{\mathrm{c}}$ & $0.59^{\mathrm{a}}$ \\
\hline $\mathrm{T}_{2}$ (Ashwagandha 1\%) & $12.13^{\mathrm{a}}$ & $3.79^{\mathrm{a}}$ & $33.86^{\mathrm{a}}$ & $23.29^{b}$ & $72.45^{\mathrm{b}}$ & $0.32^{\mathrm{b}}$ \\
\hline $\mathrm{T}_{3}($ Vitamin $\mathrm{C} 0.05 \%)$ & $12.36^{\mathrm{a}}$ & $3.85^{\mathrm{a}}$ & $32.71^{b}$ & $21.93^{c}$ & $74.05^{\mathrm{a}}$ & $0.29^{c}$ \\
\hline $\begin{array}{l}T_{4}(\text { Ashwagandha } \\
\text { 0.5\%+ Vitamin C } \\
0.025 \%)\end{array}$ & $12.41^{\mathrm{a}}$ & $3.89^{\mathrm{a}}$ & $33.93^{\mathrm{a}}$ & $22.46^{\mathrm{cb}}$ & $73.25^{\mathrm{ab}}$ & $0.30^{\mathrm{cb}}$ \\
\hline SEM & 0.13 & 0.04 & 0.17 & 0.35 & 0.45 & 0.01 \\
\hline P value & $<0.05$ & $<0.05$ & $<0.05$ & $<0.05$ & $<0.05$ & $<0.05$ \\
\hline
\end{tabular}

Means values bearing different superscripts differ significantly $(\mathrm{P}<0.05)$ column wise

Table.4 Effect of vitamin C, Ashwagandha (Withania somnifera) and their combination on carcass traits (\% of live weight) of broiler birds during hot weather (Mean \pm S.E.M; $N=60$ )

\begin{tabular}{|l|c|c|c|c|}
\hline Treatments & $\begin{array}{c}\text { Dressed } \\
(\mathbf{\%})\end{array}$ & $\begin{array}{c}\text { Eviscerated } \\
(\mathbf{\%})\end{array}$ & $\begin{array}{c}\text { Giblet } \\
(\mathbf{\%})\end{array}$ & $\begin{array}{c}\text { Drawn } \\
(\mathbf{\%})\end{array}$ \\
\hline $\mathbf{T}_{\mathbf{1}}($ Control) & $70.10^{\mathrm{b}}$ & $60.66^{\mathrm{b}}$ & $4.74^{\mathrm{c}}$ & $65.40^{\mathrm{b}}$ \\
\hline $\mathbf{T}_{\mathbf{2}}$ (Ashwagandha 1\%) & $71.96^{\mathrm{a}}$ & $62.04^{\mathrm{a}}$ & $5.00^{\mathrm{b}}$ & $67.04^{\mathrm{a}}$ \\
\hline $\mathbf{T}_{\mathbf{3}}($ Vitamin C 0.05\%) & $71.95^{\mathrm{a}}$ & $62.25^{\mathrm{a}}$ & $5.20^{\mathrm{a}}$ & $67.44^{\mathrm{a}}$ \\
\hline $\mathbf{T}_{\mathbf{4}}$ (Ashwagandha 0.5\%+ & $72.03^{\mathrm{a}}$ & $62.44^{\mathrm{a}}$ & $5.08^{\mathrm{ab}}$ & $67.51^{\mathrm{a}}$ \\
\hline Vitamin C 0.025\%) & & & & \\
\hline SEM & 0.20 & 0.19 & 0.06 & 0.20 \\
\hline P value & $<0.05$ & $<0.05$ & $<0.05$ & $<0.05$ \\
\hline
\end{tabular}

Means values bearing different superscripts differ significantly $(\mathrm{P}<0.05)$ column wise 


\section{Carcass yield}

The mean carcass yield (percentage of live weight) of broilers reared under different treatments, recorded at sixth week of age is presented in Table 4. The dressed yield percentage of supplemented groups were significantly $(\mathrm{P}<0.05)$ higher from the control. Vitamin $C$, Ashwagandha and their combination significantly improved the carcass yield in hot weather. All the supplemented group birds had higher giblet percentage. The giblet percentage of vitamin C $\left(\mathrm{T}_{2}\right)$ group was higher than Ashwagandha and control but similar to the combination $\left(\mathrm{T}_{4}\right)$ group. Analysis showed significant $(\mathrm{P}<0.05)$ low eviscerated percent in the control group $\left(\mathrm{T}_{1}\right)$ birds compared to treatment groups whereas the supplemented groups had significantly $(\mathrm{P}<0.05)$ higher drawn yield percentages from control.

Samarth et al., (2002) reported that supplementation of Ashwagandha at $0.5 \%$ level increased the dressed yield in broilers. The dressing percentage in the Ashwagandha supplemented broilers was $85.7 \%$ as compared to $82.49 \%$ in control group. Edible meat percentages were $72.84 \%$ and $70.53 \%$ in the supplemented and control groups, respectively. Choudhari et al., (2006) reported higher dressed percentage in Japanese quails fed Ashwagandha supplemented diet than in control. The findings are in concurrence with Vasanthakumar et al., (2015) who also reported better performance of commercial broilers when supplemented with Ashwagandha extracts at different inclusions levels for alleviating heat stress.

Vitamin C increased carcass yield in hot environment in the present study which is in similar to the findings of Lohakare et al., (2004); Celik and Ozturkcan (2003). Higher carcass yield may be due to higher final body weight, better conformation and finish in the
Ashwagandha, vitamin $\mathrm{C}$ and combination supplemented birds due to adaptogenic, antistress and growth promoting factors like that with anolides. Higher giblet percent in supplemented birds may be due to higher final body weight and subsequently higher giblet weight.

From the above discussion it may be concluded that supplementation of Ashwagandha, vitamin $\mathrm{C}$ and their combination improved the hematological values viz. haemoglobin $(\mathrm{Hb})$, TEC, TLC, and DLC (Heterophil and Lymphocyte percent). The $\mathrm{H}$ : $\mathrm{L}$ ratio was better in the supplemented groups in respect to the control groups. The carcass yield was significantly higher in the supplemented Ashwagandha, vitamin $\mathrm{C}$ and their combination group showing better return however, further study of this finding is required.

\section{References}

Bernet, D., Schimidt, H., Meier, W., Burkhardt-Holm, P., and Wahli, T. (1999). Histopathology in fish: proposal for a protocol to assess aquatic pollution. Journal of Fish Diseases, 22(1): 25-34.

Dezfuli, B.S., Giari, L., Simoni, E., Menegatti, R., Shinn, A.P., and Manera, M. (2007). Gill histopathology of cultured European sea bass, Dicentrarchus labrax (L.), infected with Diplectanum aequans (Wagener 1857) Diesing 1958 (Diplectanidae: Monogenea). Parasitology Research, 2007; 100(4): 707-713.

Agarwal, R., Diwanay, S., Patki, P. and Patwardhan, B. (1999). Studies on immunomodulatory activity of Withania somnifera (Ashwagandha) extracts in experimental immune inflammation. Journal of Ethnopharmacology, 67(1):27-35. 
Akotkar, N.S. (2004). Effect of supplementation of medicinal plant Withania somnifera on performance of broiler production. Unpublished M.V.Sc Thesis; P.G.I.V.A.S, Akola, M.A.F.S.U. Nagpur, India.

Altan, O., Pabuçcuoğlu, A., Altan, A., Konyalioğlu, S. and Bayraktar, H. (2003). Effect of heat stress on oxidative stress, lipid peroxidation and some stress parameters in broilers. British Poult Sci, 44(4): 545-550.

Bedanova, I., Voslarova, E., Vecereck, V., Strakova, E. and Suchy, P. 2003. The haematological profile of broilers under acute and chronic heat stress at $30 \pm 1{ }^{\circ} \mathrm{C}$ level. Folia Veterinaria, 47 (4): 188192.

Bhattacharya, S.K., Satyan, K.S. and Ghosal, S. (1997). Antioxidant activity of glycowithanolides from Withania somnifera. Indian J Experimental Biol, 35 (3): 236-239.

Biswas, P., Sharma, R.K. and Biswas, A. 2012. Effect of dietary supplementation of Ashwagandha (Withania somnifera) and ascorbic acid on production performance of broiler birds on hematological profile and carcass traits of broiler birds. Indian Journal of Poultry Science, 47(3):403-405.

Cahaner, A. and Leenstra, F. (1992). Effect of high temperature on growth and efficiency of male and female broilers from lines selected for high weight gain, favorable feed conversion and high or low fat content. Poultry Science, 71 (8): 1237-1250.

Celik, L. and Ozturkcan, O. (2003). Effects of dietary supplemental L-carnitine and Vitamin $\mathrm{C}$ on performance, carcass composition and plasma L-carnitine concentration of broiler chicks reared under different temperature. Archive Tierernahr, 57(1):27-38.

Choudhari, A.J., Deshmukh, G.B., Ramateke,
B.N. and Zanzad, A.A. (2006). Effect of dietary supplementation of Ashwagandha on Japanese Quails during summer. Indian Journal of Animal Nutrition, 23:253-255.

Daisy, K.M.., Patel, M., Kumar, A., Ahmad, A.H., Arya, R. and Hore, S.K. (2008). Effect of Ashwagandha on haematobiochemical profile of broilers. Indian Veterinary Journal, 85: 327-328.

Duncan, B.D. (1955). Multiple range and multiple F tests. Biometrics, 11: 1-12.

Gupta, G.L. and Rana, A.C. (2007). Withania somnifera (Ashwagandha): A Review. Pharmacognosy Reviews, 1:129-136.

Jamadar, S.J. and Jalnapurkar, B.V. (1995). Effect of high ambient temperature on iron status of broilers. Indian Veterinary Journal 72: 577-579.

Jayram, S., Walwaikar, P.P. and Rajadhyaksha, S.S. (1993). Evaluation of efficacy of a preparation containing combination of Indian medicinal plants in patients of generalized weakness. Indian Drugs, 30(10): 498-500.

Kidd, P.M. (1997). Glutathione: systemic protectant against oxidative and free radical damage. Alternative Medicine Review, 1:155-76.

Lohakare, J.D., Chae, B.J. and Hann, T.W. (2004). Effect of feeding methods (water vs. feed) of vitamin c on growth performance and carcass characteristics in broiler chicken. Asian-Australasian Journal of Animal Science, 17 (8): 1112-1117.

McKee, J.S., Harrison, P.C. and Riskowski, G.L. (1997). Effects of supplemental Vitamin $\mathrm{C}$ on the energy conversion of broiler chicks during heat stress and feed withdrawal. Poultry Science, 76(9): 1278-1286.

Pradhan, N.R. (1995). Effect of Stressroak on the performance of broilers. Indian Journal of Poultry Science, 30(1): 8284. 
Puthpongsiriporn, U., Scheideler, S.E., Sell, J.L. and Beck, M.M. (2001). Effects of vitamin $\mathrm{E}$ and $\mathrm{C}$ supplementation on performance, in vitro lymphocyte proliferation, and antioxidant status of laying hens during heat stress. Poultry Science, 80: 1190-1200.

Puvadolpirod, S. and Thaxton, J.P. (2000). Model of physiological stress in chickens 2. Dosimetry of adrenocorticotropin. Poultry Science, 79:370-376

Rajeshwar, N.R., Pande, C.B. and Kiran, A. (2001). Effect of Zeetress on broiler performance: A study. Pashudhan, 16 (5): 4.

Samarth, V.R., Jagtap, D.G., Dakshinkar, N.P., Nimbulkar, M.V. and Kohthekar, M.D. (2002). Effect of Ashwagandha root powder (Withania somnifera) on the performance of broilers. Indian
Veterinary Journal, 79(7):733-734.

Shastry, G.A. (1983). Veterinary clinical pathology. 2nd edn., CBS Publishers and Distributors, New Delhi.

Snedecor, G.W. and Cochran, W.G. (1985). Statistical Methods. $8^{\text {th }}$ Ed. The Iowa State University Press, Iowa (U.S.A).

Vasanthakumar, P., Pangayarselvi, B., Sasikumar, P., Chandrasekaran, D., Doraisamy, K.A. and Purushothaman, M.R. (2015). Performance of broilers fed ashwagandha (Withania somnifera) incorporated diets during summer season for alleviating heat stress. Indian Journal of Animal Research, (49): 333335.

Whitehead, C.C. and Keller, T. 2003. An update on Vitamin C in poultry. World's Poultry Science Journal, 59: 161-184.

\section{How to cite this article:}

Probhakar Biswas, Ram Kumar Sharma, Avishek Biswas and Indrajit Kar. 2020. Effect of Ashwagandha (Withania somnifera) and Vitamin $\mathrm{C}$ on Hematological Profile and Carcass Traits of Broiler Birds. Int.J.Curr.Microbiol.App.Sci. 9(10): 783-791. doi: https://doi.org/10.20546/ijcmas.2020.910.094 